\title{
THE SITE OF ORIGIN OF LUNG CANCER AND ITS RELATION TO HISTOLOGICAL TYPE
}

\author{
BY \\ J. B. WALTER AND D. M. PRYCE \\ From the Bland Sutton Institute of Pathology and Institute for Clinical Research, Middlesex Hospital, the \\ Department of Morbid Anatomy, St. Mary's Hospital, Lona'on, and Harefield Hospital
}

(RECEIVED FOR PUBLICATION MARCH 23, 1955)

Since the recognition of lung cancer as a common disease, it has been the accepted teaching that the majority of these tumours arise in the major bronchi near the hilum. Fried (1938) in 152 cases found " that the tumour always originates in the mainstem bronchus or in some of its smaller branches but not in those whose diameter is about $10 \mathrm{~mm}$. or less." Boyd (1950) stated: "The hilus tumour is by far the commonest variety. Over $90 \%$ of the cases fall into this group." Willis (1948) said: "At least three-quarters of the tumours demonstrably arise in the large bronchi, either the main bronchi or the lobar bronchi in or near the hilar region." Davidson, Smithers, and Tubbs (1951) wrote: "In a large proportion of cases the growth has a more or less typical site of origin, a few centimetres below the division of a main bronchus, at the point where the smaller bronchi take off." Strang and Simpson (1953) estimate that only $7-9 \%$ of all primary cancers have a peripheral origin, while Bryson and Spencer (1951) put the figure at $2.8 \%$.

The view that the majority of lung cancers arise in the main bronchi is based mainly on post-mortem studies of the disease in its terminal stages when the tumour has, in most instances, attained a large size: direct spread and lymphatic metastasis have combined to produce the familiar hilar mass involving lung, bronchi, vessels, and mediastinal structures alike. Gross involvement of the large hilar bronchi is usually present and this has been assumed to be the origin; it is doubtful whether this assumption is often justified. The appearances are occasionally mimicked by metastatic growth or Hodgkin's disease. They may also be produced by lung tumours of peripheral type involving the large bronchi secondarily, either by direct extension or by lymphatic metastasis (Fig. 1). From examination of large tumours it is impossible to estimate the frequency of this occurrence, and it is only in the small or early cases that the site of origin is likely to be recognizable.

In a stimulating paper Raeburn (1951) put forward the view that most lung cancers had a peripheral origin. Having previously failed to find small tumours in the large bronchi in a series of patients dying from other causes, he was prompted to slice up the whole of both lungs and examine all suspicious nodules and scars microscopically. In 400 cases he found four small tumours of peripheral type and again none in the large bronchi. One of the tumours, an adenocarcinoma which had metastasized to a rib, was $1.2 \mathrm{~cm}$. in diameter, but the other three were only 1 to $2 \mathrm{~mm}$. in diameter. These minute lesions were described (Raeburn and Spencer, 1953) as resembling the carcinoid type of adenoma, but were provisionally classified as " oatcell " tumours; two of them were in women. Such lesions are well recognized and are known to be more common in women (Prior and Jones, 1952), but it is by no means certain that they are true malignant tumours: it is possible that they are latent carcinomata as suggested by Franks (1954). Raeburn and Spencer (1953) added six cases to those described by Raeburn in 1951; these included a small tumour of central type and another of the minute "oat-cell" lesions. Assuming that the peripheral lesions were all neoplastic, this gave a total of 10 tumours, nine of which were peripheral and only one central.

The foregoing work is important, but the labour involved, the meagreness of the results, and the doubtful nature of some of the lesions diminish its value so far as the present problem is concerned. Examination of specimens resected by the surgeon offers more hope of a solution; in these cases obvious examples of central tumours are common, but all recent reports on this material show that the peripheral type is also common. Of 263 resected lung tumours reported from the Mayo 


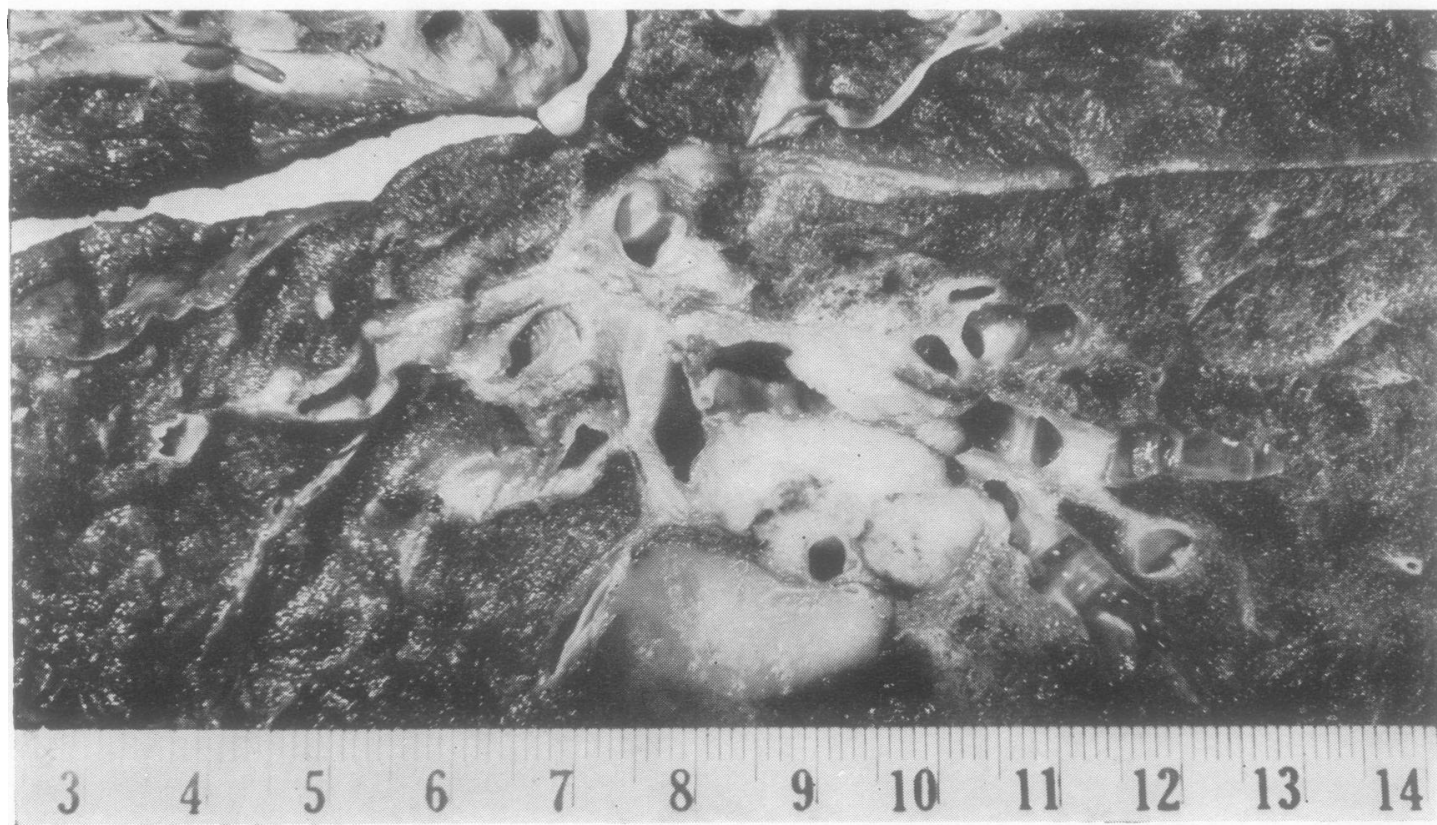

(b)

FiG. 1.-Peripheral growth (probable) with glandular spread and secondary bronchial involvement. (a) Right upper lobe showing well-defined rounded primary tumour in the anterior segment. The apical segment (top right) shows a patch of mucous consolidation and several bronchi are filled with mucus. Microscopy showed oat-cell carcinoma with some rosettes and early squamous metaplasia in some parts. (b) The same lobe sectioned nearer the hilum. Several glands are replaced by growth and the adjacent apical and apico-posterior bronchiare invaded from without. Branches of the apical bronchus (right) are dilated and filled with mucus, while the translucent area anterior (lower centre) to the growth is due to mucous consolidation. Other hilar and the carinal glands were extensively invaded. 
Clinic (McDonald, McBurney, Carlisle, and Patton, 1951; McBurney, McDonald, and Clagett, 1951; Carlisle, McDonald, and Harrington, 1951 ; Patton, McDonald, and Moersch, 1951a and b), nearly 26\% were regarded as peripheral. Ochsner, DeBakey, Dunlap, and Richman (1948) found nearly $50 \%$ of 190 tumours to be situated distal to the primary bronchi. Phillips, Basinger, and Adams (1950) examined 36 surgical tumours by means of a wholesection technique and found $50 \%$ to be peripheral. Our own results with surgical material agree closely with the last reported series. We have long been aware of the great frequency of the peripheral type in surgical material, but we have evidence for thinking that its true incidence (in post-mortem material) is even higher.

\section{Material AND Definition of Terms}

The material consisted of 207 surgically removed tumours the histological classification of which has been previously reported (Walter and Pryce, p. 107). Each tumour was placed in one of four groups according to the average diameter of the primary growth, the following arbitrary standards being used :

Small : $2 \mathrm{~cm}$. or less in diameter.

Medium: Greater than $2 \mathrm{~cm}$. but less than $5 \mathrm{~cm}$ diameter.

Large : Greater than $5 \mathrm{~cm}$. but less than $8 \mathrm{~cm}$. diameter. Giant: Over $8 \mathrm{~cm}$.

For the purposes of measurement, growth in lymph nodes was disregarded whenever possible; in some extensive growths, usually of unknown origin, it was not possible to distinguish between primary and secondary metastatic growth. In such cases the whole mass was measured.

The tumours were then grouped according to their site of origin. It is reasonable to suppose that tumour formation can occur in any part of the lung, and from a practical point of view four sites may be defined:

(1) The large nominate bronchi: this field extends from the origin of the main bronchus to the point of division of the segmental bronchi. We have classified tumours arising in these large bronchi as "central."

(2) The smaller bronchi: these include all nakedeye branches of the large nominate bronchi. Tumours arising in these bronchi have been termed " intermediate."

(3) The minute bronchi and bronchioles: tumours arising in this field have been termed " peripheral."

(4) The alveoli themselves: whether a carcinoma can arise in the alveolar epithelium is debatable; the two cases of so-called alveolar-cell carcinoma that we encountered were considered to arise in the terminal bronchioles and therefore classified as peripheral.

Much confusion has arisen as a result of the terms " central" and " hilar" having been used synonymously. It is obvious that a tumour arising in a segmental bronchus may not be near the hilum and similarly a peripheral tumour arising in a bronchiole adjacent to the main bronchus may well appear as a hilar mass. We have avoided the term "hilar" and have used the terms central, intermediate, and peripheral as defined above. Our results may therefore be at variance with those who have used the same terms in a different sense, e.g., Carlisle and others (1951), who defined a truly peripheral tumour as one that " lay more than $4 \mathrm{~cm}$. from the main bronchus or its continuation as the main lower lobe bronchus."

The site of origin of some tumours was obvious; with others the identification called for considerable judgment and was a matter of probability, while with the remaining tumours it was impossible to tell the site of origin. These three groups were designated respectively " definite," " probable," and " unknown."

\section{Central Tumours}

No difficulty was experienced with these tumours when growth had not spread beyond the bronchus of origin. In some, the tumour had extended into peribronchial structures involving interstitial tissues and adjacent lymph nodes; in others axial spread had occurred either in the form of intrabronchial tongues of growth or more frequently as a result of mural infiltration. In cases such as these, where no alveolar tissue was invaded, the tumour was still obviously central, but the exact bronchus of origin was more difficult to recognize; examination of the obstructive phenomena in the lung beyond the growth often provided important clues. Central tumours even when small cause obstruction at the site of origin, and the changes beyond this are characteristically of a simple nature with minimal infection (Fig. 2). Where bronchi are blocked by subsequent tumour spread, the changes in the lung distally are more often associated with infection, abscess formation, or lipoid pneumonia (Fig. 3).

Central tumours in which adjacent lung was invaded presented more difficulty. Where such invasion was slight we still felt justified in regarding the tumour as definitely central (Fig. 4). With more marked alveolar invasion the possibility of a peripheral focus could not be ignored and these were classified as probably central, provided no adjacent peripheral focus or area of scarring could be found. When alveolar invasion was extensive, even though 


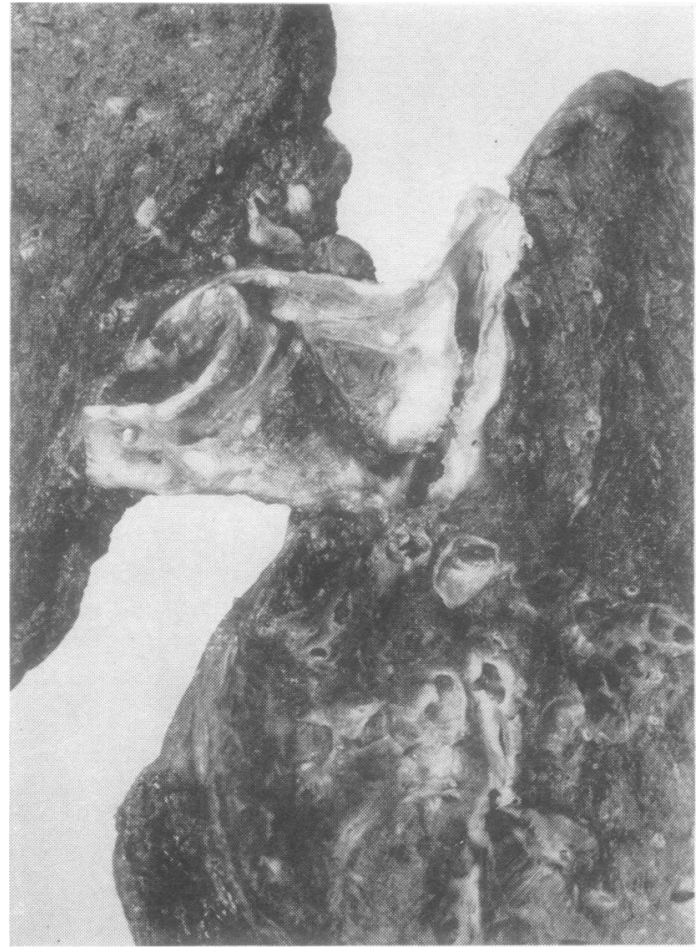

FIG. 2.-The right lower (right) and middle lobes (top left): the bronchi are cut longitudinally and turned towards the middle lobe. There is a small central tumour (definite) of the lower lobe bronchus below the orifice of its apical branch. The lung beyond the obstruction is partially collapsed and shows some simple bronchiectasis. Microscopy showed squamous-cell carcinoma.

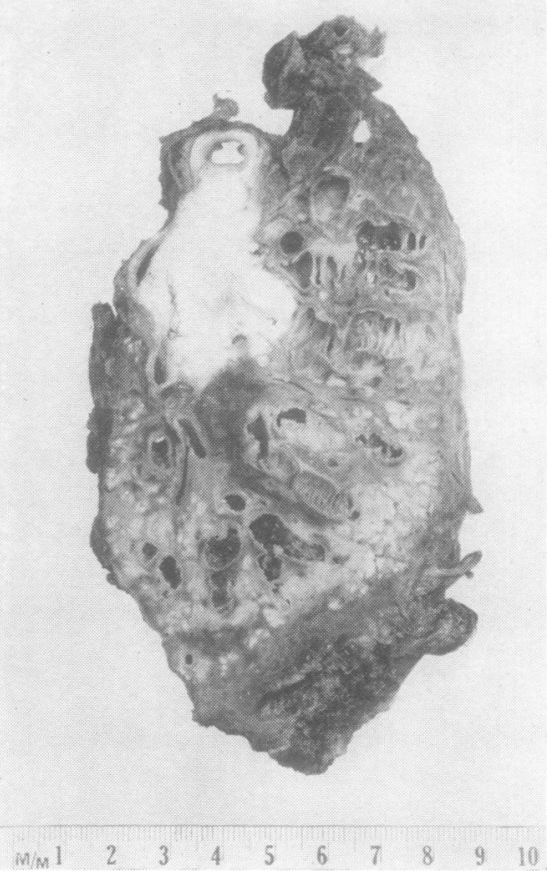

FIG. 3.-Right lower lobe with upper and middle lobe bronchi attached. There is growth blocking the apical bronchus (top right) and the segment shows gross bronchiectasis and carnification. Tumour has spread to involve the main lower lobe bronchus and just reaches the upper lobe bronchus (seen in transverse section) and the middle lobe bronchus. The basal segments of the lower lobe show bronchiectasis and marked lipoid pneumonia. This is a central (definite) squamous-cell lipoid pneumonia. This is a cent
carcinoma of the apical bronchus.

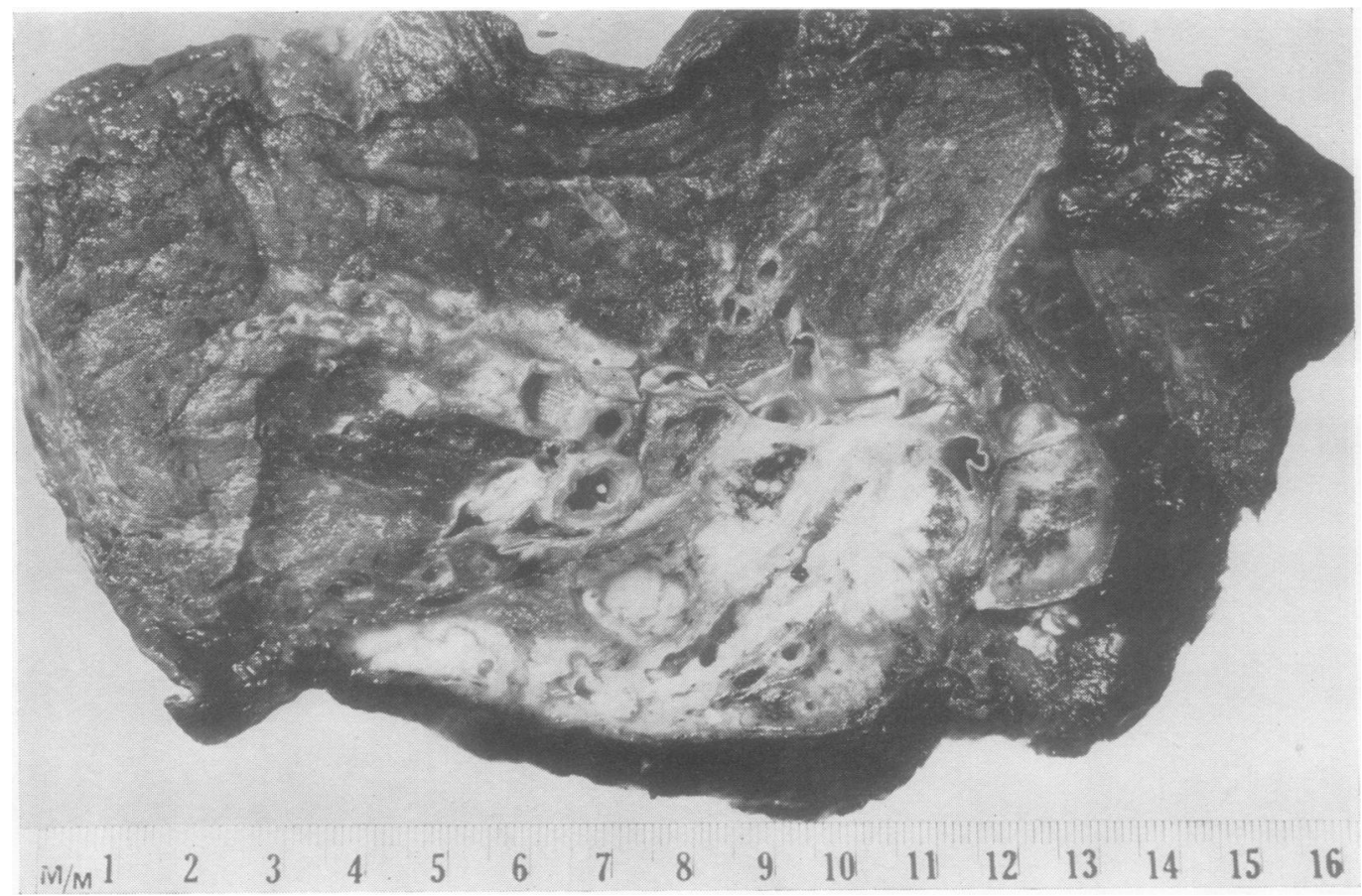

FIG. 4.-Left lung showing central (definite) carcinoma of the lingular bronchus: the adjacent glands are invaded and there is limited extension into surrounding lung parenchyma. Microscopy showed squamous-cell carcinoma with some giant cell formation. 
the appearances favoured a central origin, the growth was placed in the " unknown" group.

\section{The INTERMEDIATE Group}

There were only seven cases in which a growth of central type was recognized as arising in a medium-sized bronchus. Intermediate tumours may not be as uncommon as this figure suggests, for obstruction to the smaller air passages leads to less obvious changes than with large bronchus block. By the time these tumours are resected, it is possible that the original site of origin has been obliterated, and therefore cases of this type may be included in the unknown or central groups.

\section{Peripheral Tumours}

The recognition of peripheral growth presented no difficulty when no naked-eye bronchus was involved. Fig. 5 shows a typical example: the edge of the tumour is crenated, the centre is heavily pigmented and fibrotic, while the surrounding tumour is grey, due to the normal deposit of carbon in the alveolar tissue. Central scarring was found in $55 \%$ of peripheral tumours and was often present even when the tumour was large (Fig. 6). In 35\% of cases the tumour contained a cavity over $2 \mathrm{~cm}$. in diameter and in most of these cases scarring was absent. In some peripheral tumours, however, there was invasion of naked-eye bronchi. Sometimes a bronchus, although invaded and surrounded by growth, presented an intact mucosa - an appearance not seen in any tumour of undoubted central origin. In other cases several bronchi at the periphery of a tumour mass were invaded, making origin from any of them unlikely. No case was put in the "definite" group unless a bronchial origin could be excluded. When the appearances suggested a peripheral tumour but the bronchial involvement left an element of doubt the case was placed in the " probable" group.

\section{The UnKNOWN GrouP}

It was impossible to be sure of the site of origin in some cases because the involvement of the bronchi and lung was too extensive. In other cases this was because there were two foci of growth. Fig. 7 is an example of the latter type of case. The growth blocking the apical bronchus resembles a central tumour, but in the lung below this there was a separate focus which could have been the primary peripheral growth, an implantation metastasis, or possibly even another primary growth. Some oat-cell carcinomata which were impossible to "site" were composed of a peculiar diffuse type of growth involving lung, bronchi, interstitial tissue, and lymph nodes, making it impossible to identify the point of origin (Fig. 8).

\section{RESULTS}

The results of the classification of the 207 cases are shown in Table I. We were confident about the site of origin in 123 cases $(59.4 \%)$, and in a further

TABLE I

THE SITE OF ORIGIN OF 207 SURGICALLY RESECTED LUNG CANCERS

\begin{tabular}{|c|c|c|c|c|}
\hline & & Definite & Probable & Total \\
\hline $\begin{array}{l}\text { Central . . } \\
\text { Intermediate } \\
\text { Peripheral }\end{array}$ & $\begin{array}{l}. . \\
\therefore\end{array}$ & $\begin{array}{r}58 \\
4 \\
61\end{array}$ & $\begin{array}{r}10 \\
3 \\
25\end{array}$ & $\begin{array}{r}68 \\
7 \\
86\end{array}$ \\
\hline $\begin{array}{r}\text { Total } \\
\text { Unknown }\end{array}$ & .. & 123 & 38 & $\begin{array}{r}161 \\
46\end{array}$ \\
\hline $\begin{array}{c}\text { Total no } \\
\text { cases }\end{array}$ & $\begin{array}{l}\text { of } \\
\ldots\end{array}$ & & & 207 \\
\hline
\end{tabular}

$38(18.4 \%)$ we felt justified in offering an opinion. In only 46 tumours $(22.2 \%)$ were we unwilling to commit ourselves. Of the 123 definitely sited tumours, nearly one half $(49.6 \%)$ were peripheral; if the "probable" cases are also included the figure is $53 \%$.

The relationship between tumour size and the frequency with which the site of origin can be determined is shown in Table II. It is evident that

TABLE II

RELATIONSHIP BETWEEN TUMOUR SIZE AND FREQUENCY WITH SITE OF ORIGIN DETERMINED

\begin{tabular}{cc|c|c|c|c}
\hline & & Definite & Probable & Unknown & Total \\
\cline { 3 - 5 } Small & $\ldots$ & 19 & 3 & 2 & 24 \\
Medium & $\cdots$ & 59 & 26 & 22 & 107 \\
Large.. & $\cdots$ & 33 & 7 & 20 & 60 \\
Giant &. & 12 & 2 & 2 & 16 \\
\hline \multicolumn{1}{c|}{ Total } &. & 123 & 38 & 46 & 207 \\
\hline
\end{tabular}

* Each column shows the number of tumours (resected specimens) in which the site of origin was considered definite, probable, or unknown.

with small tumours it is relatively easy to be certain of the site of origin: it should be noted, however, that even with these it was impossible to site two cases. With medium sized tumours it was impossible to ascertain the origin in 22 cases $(21 \%)$, while of the large growths about a third $(33 \%)$ could not be sited. This increasing difficulty in recognizing the site of origin with increase in tumour size was to be expected. The difficulties lessened, however, when it came to the giant tumours; of 16 no less than 12 were obviously peripheral, two more were probably peripheral, and in only two cases $(12.5 \%)$ was it impossible to come to any 


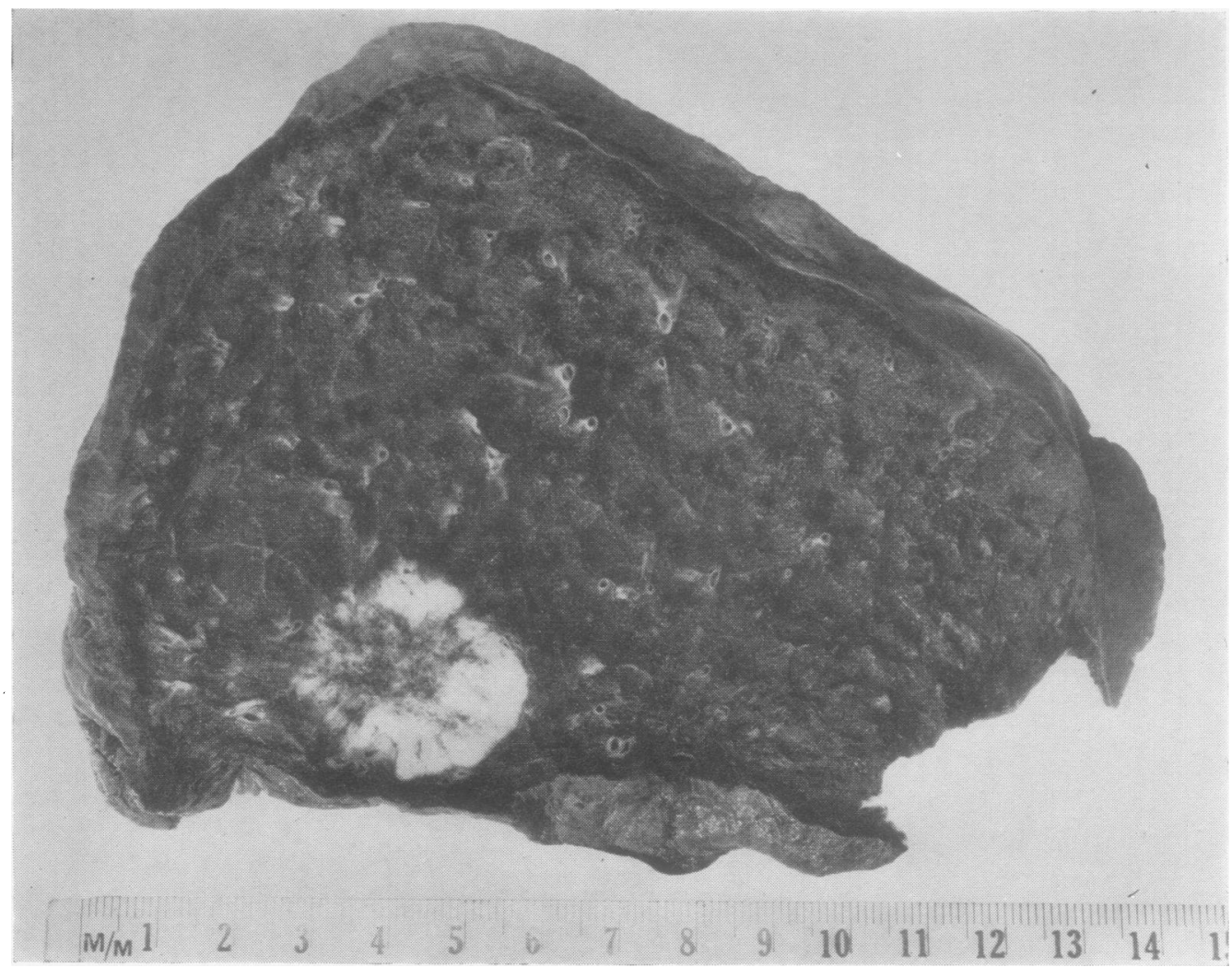

Fig. 5.-Typical peripheral carcinoma (definite) in the anterior segment of the right upper lobe; an area of scarring is present. Although the bronchopulmonary glands were free there was a large mass of invaded hilar glands. Microscopy showed adenocarcinoma with tubule formation and areas of clear cell formation.

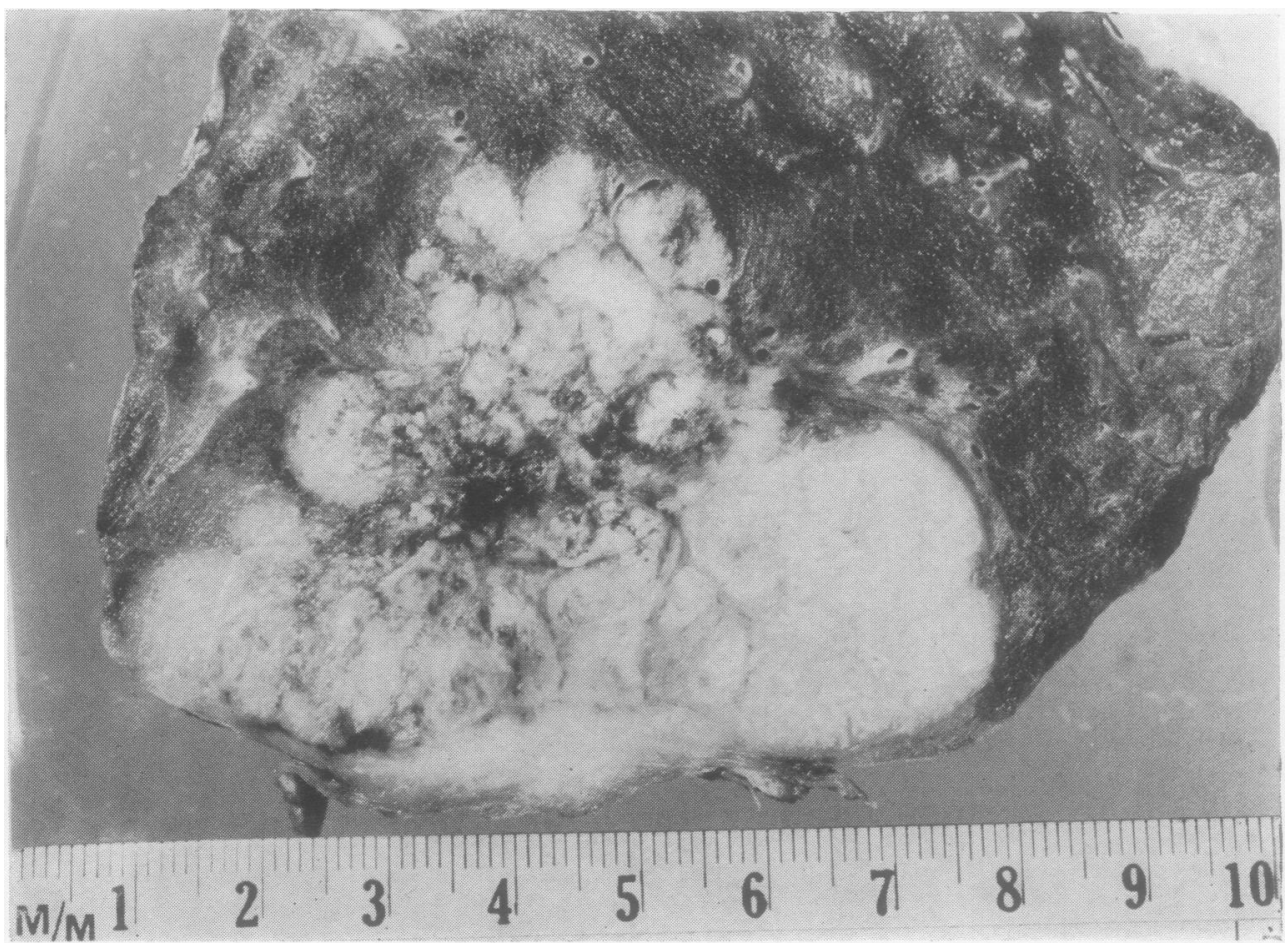

FiG. 6. - Right upper lobe showing a large peripheral tumour (definite) occupying the apical segment. There is a central pigmented scar and the overlying pleura is invaded. Microscopy showed oat-cell carcinoma with some rosette formation. 


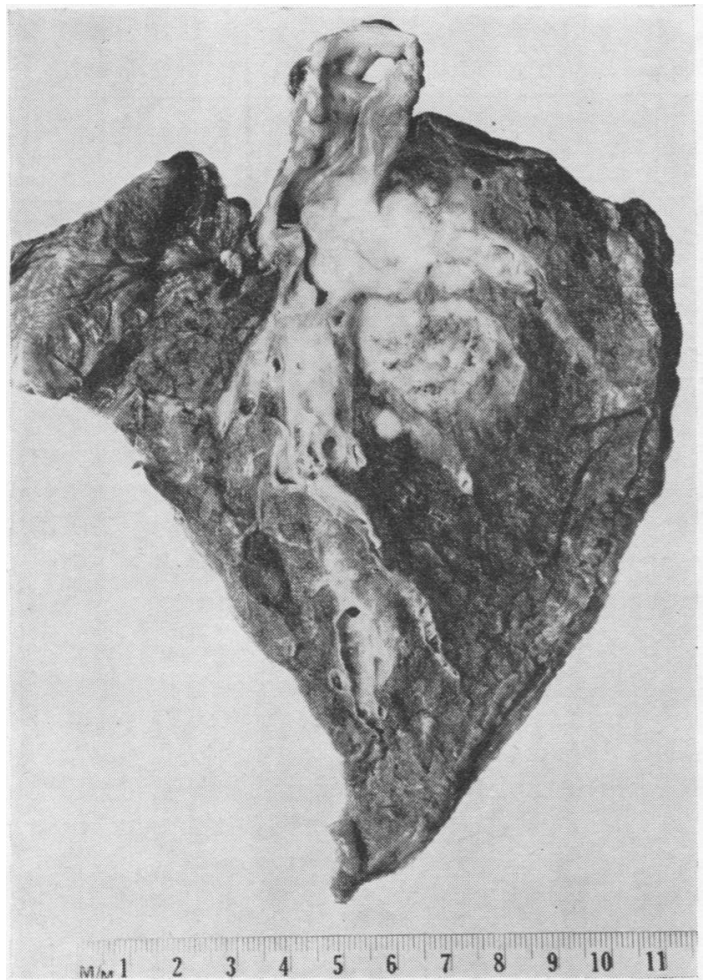

FIG. 7.-Right lower and middle lobes with main bronchus attached The lower lobe apical bronchus is invaded and blocked by growth; in the lung substance below this is a separate mass of tumour. This case was placed in the unknown group. Microscopy showed adenocarcinoma with extensive squamous metaplasia.

conclusion. This is probably because in this series of resected specimens the giant central growths and the peripheral tumours with hilar extension were excluded by their inoperability.

Table III analyses the relationship between the size of the tumour and the site of origin in the 123 "definite" cases.

TABLE III

RELATIONSHIP BETWEEN SIZE OF TUMOUR AND SITE OF ORIGIN IN 123 RESECTED TUMOURS WITH ORIGIN DEFINITELY LOCATED

\begin{tabular}{ll|c|c|c|c}
\hline \multicolumn{1}{r|}{ Size } & & Peripheral & $\begin{array}{c}\text { Inter- } \\
\text { mediate }\end{array}$ & Central & Total \\
\hline Small .. & $\ldots$ & 1 & 1 & 17 & 19 \\
Medium & $\ldots$ & 20 & 3 & 36 & 59 \\
Large ... & $\ldots$ & 28 & 0 & 5 & 33 \\
Giant.. &.. & 12 & 0 & 0 & 12 \\
\hline
\end{tabular}

It shows that nearly all the definitely sited small tumours were central. Only one, found by mass radiography, was definitely peripheral. Table III also shows that this series of surgical resections did

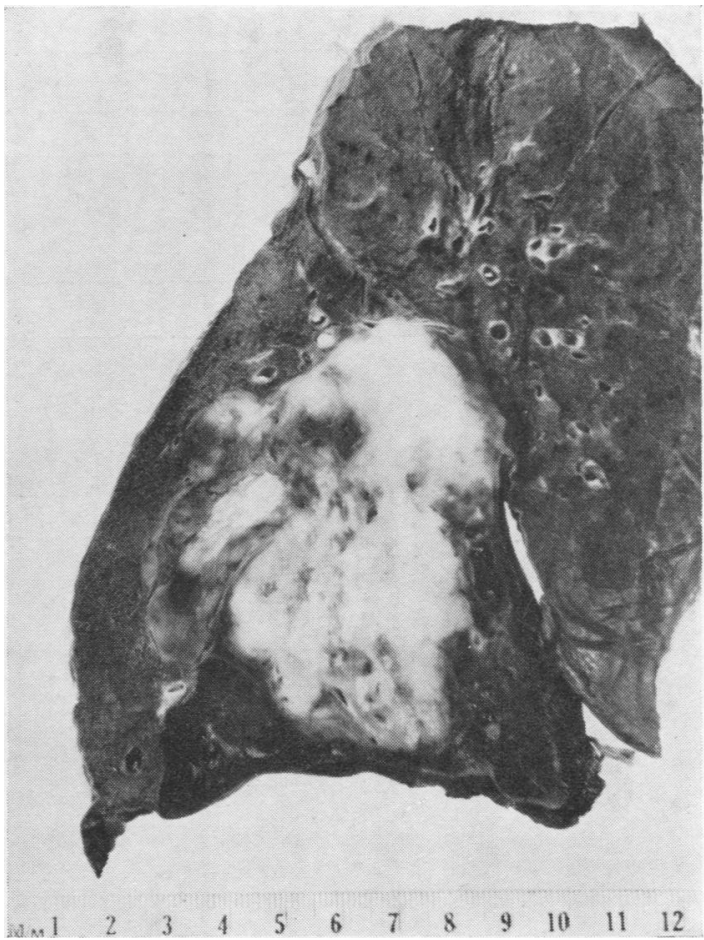

FIG. 8.-Left lung showing large tumour of unknown origin in the lower lobe. There is extensive involvement of bronchi and lung parenchyma; below the growth the lung is infarcted. Microscopy showed undifferentiated oat-cell carcinoma.

not include a single giant tumour which was definitely central.

TABLE IV

HISTOLOGY OF 207 RESECTED LUNG CANCERS SUBDIVIDED TO SHOW RELATIONSHIP TO SITE OF ORIGIN

\begin{tabular}{|c|c|c|c|c|c|c|c|c|}
\hline \multirow{2}{*}{$\begin{array}{l}\text { Histological } \\
\text { Type }\end{array}$} & \multicolumn{2}{|c|}{ Central } & \multicolumn{2}{|c|}{$\begin{array}{c}\text { Inter- } \\
\text { mediate }\end{array}$} & \multicolumn{2}{|c|}{$\begin{array}{c}\text { Peri- } \\
\text { pheral }\end{array}$} & \multirow{2}{*}{ Known } & \multirow{2}{*}{ Tota } \\
\hline & $\begin{array}{l}\text { Def- } \\
\text { inite }\end{array}$ & $\begin{array}{c}\text { Prob- } \\
\text { able }\end{array}$ & $\begin{array}{l}\text { Def- } \\
\text { inite }\end{array}$ & $\begin{array}{l}\text { Prob- } \\
\text { able }\end{array}$ & $\begin{array}{l}\text { Def- } \\
\text { inite }\end{array}$ & $\begin{array}{l}\text { Prob- } \\
\text { able }\end{array}$ & & \\
\hline \multirow{3}{*}{$\begin{array}{l}\text { Squamous-cell } \\
\text { carcinoma ... } \\
\text { Adenocarcinoma } \\
\text { Oat-cell carcin- } \\
\text { oma } \\
\text { Polygonal cell } \\
\text { carcinoma .. } \\
\text { " Malignant } \\
\text { adenoma ".. }\end{array}$} & $\begin{array}{r}45 \\
0\end{array}$ & $\begin{array}{r}10 \\
0\end{array}$ & $\begin{array}{l}\mathbf{2} \\
\mathbf{0}\end{array}$ & $\begin{array}{l}3 \\
0\end{array}$ & $\begin{array}{l}23 \\
24\end{array}$ & $\begin{array}{r}12 \\
3\end{array}$ & $\begin{array}{r}30 \\
5\end{array}$ & $\begin{array}{r}125 \\
32\end{array}$ \\
\hline & 12 & 0 & 0 & 0 & 7 & 4 & 10 & 33 \\
\hline & 1 & 0 & 1 & 0 & 7 & 6 & 1 & 16 \\
\hline & & & & & & & & \\
\hline Total & 58 & 10 & 4 & 3 & 61 & 25 & 46 & 207 \\
\hline
\end{tabular}

Table IV shows the relationship between histology and site of origin. It can be seen that the squamous-cell carcinomata are rather more frequently central $(44 \%)$ than either peripheral $(28 \%)$ 
TABLE V

HISTOLOGY OF 207 RESECTED LUNG CANCERS SUBDIVIDED TO SHOW RELATIONSHIP TO SIZE OF TUMOUR

\begin{tabular}{|c|c|c|c|c|c|c|c|c|c|c|c|}
\hline \multirow{2}{*}{\multicolumn{2}{|c|}{ Histological Type }} & \multicolumn{2}{|c|}{ Small } & \multicolumn{2}{|c|}{ Medium } & \multicolumn{2}{|c|}{ Large } & \multicolumn{2}{|c|}{ Giant } & \multicolumn{2}{|c|}{ Total } \\
\hline & & No. & $\%$ & No. & $\%$ & No. & $\%$ & No. & $\%$ & No. & $\%$ \\
\hline $\begin{array}{l}\text { Squamous-cell carcinoma } \\
\text { Adenocarcinoma } \\
\text { Oat-cell carcinoma } \\
\text { Polygonal cell carcinoma } \\
\text { " Malignant adenoma " }\end{array}$ & $\begin{array}{l}\cdots \\
\cdots \\
\cdots \\
\cdots\end{array}$ & $\begin{array}{r}19 \\
1 \\
4 \\
0 \\
0\end{array}$ & $\begin{array}{c}79 \cdot 1 \\
4 \cdot 2 \\
16 \cdot 7 \\
0 \\
0\end{array}$ & $\begin{array}{r}67 \\
13 \\
16 \\
10 \\
1\end{array}$ & $\begin{array}{r}62.6 \\
12.1 \\
14.9 \\
9.5 \\
0.9\end{array}$ & $\begin{array}{r}35 \\
12 \\
10 \\
3 \\
0\end{array}$ & $\begin{array}{c}58 \cdot 3 \\
20 \cdot 0 \\
16 \cdot 7 \\
5 \cdot 0 \\
0\end{array}$ & $\begin{array}{l}4 \\
6 \\
3 \\
3 \\
0\end{array}$ & $\begin{array}{c}25.0 \\
37.5 \\
18.8 \\
18.7 \\
0\end{array}$ & $\begin{array}{r}125 \\
32 \\
33 \\
16 \\
0\end{array}$ & $\begin{array}{r}60.4 \\
15.5 \\
15.9 \\
7.7 \\
0.5\end{array}$ \\
\hline Total & .. & 24 & $100 \cdot 0$ & 107 & $100 \cdot 0$ & 60 & $100 \cdot 0$ & 16 & $100 \cdot 0$ & 207 & $100 \cdot 0$ \\
\hline
\end{tabular}

or unknown $(24 \%)$, while the adenocarcinomata are predominantly peripheral $(84.4 \%)$. The remaining adenocarcinomata were unknown and not one case was found to be of central type; it is possible of course that a central adenocarcinoma may be included amongst the unknown group. The oatcell growths were distributed almost equally between the central $(36.4 \%)$, the peripheral $(33.3 \%)$, and the unknown groups $(30.3 \%)$ while the polygonal cell tumours were mostly peripheral $(81.3 \%)$. The variation of histology with tumour size is shown in Table $V$. The percentage incidence of squamouscell tumours varies and steadily decreases from 79.1 in the small tumour group to 25 in those of "giant" size. On the other hand the adenocarcinomata show the greatest incidence among the giant tumours $(37.5 \%)$, and with decreasing tumour size the percentage decreases to 4.2 for the small group. These findings are not unexpected, since they are dependent upon the fact that small tumours are often central and of squamous type whilst the large and giant tumours are frequently situated peripherally where adenocarcinomata are to be expected (see Tables III and IV). Table V also shows that the percentage of oat-cell tumours is approximately 16 irrespective of tumour size; the possible significance of this is discussed later.

\section{Discussion}

Examination of 207 resected lung cancers has shown that it is possible to locate the site of origin in $77.8 \%$ and that of these $53 \%$ were peripheral. This gives little idea of the true frequency of the peripheral type, for the cases subjected to resection form a highly selected group. The exact nature of selection is disputed and estimates of the operability rate have varied from $20 \%$ to as low as $4 \%$ (Brown, 1952). Rabin and Neuhof (1934) suggested that the peripheral tumour is in a favourable position for removal, and Phillips and others (1950) support this view and state that, " although the peripherally located group represents only approximately $20-25 \%$ of all bronchiogenic carcinomas, 18 or $45 \%$ of the resected tumours of this series were in this group." $\vec{\circ}$ On the other hand some authors (e.g., Tuttle and Womack, 1934) support the opposite view that central tumours by giving rise to early symptoms are more amenable to surgical resection.

It is doubtful whether a more exacting examination of post-mortem cases would provide an answer to this problem: however, comparison of the relative frequency of the different histological types in surgical and post-mortem material suggests that the peripheral tumour is more common in the necropsy cases.

We have adopted a classification of lung cancer which has not been previously used (Walter and Pryce, p. 109) but which has proved helpful in connexion with this particular problem. We have found that the familiar oat-cell carcinomata are often differentiated and present tubular structures; we think that they should not be confused with the ordinary adenocarcinomata from which they are easily distinguishable. Using this classification it was found that, of 32 resected adenocarcinomata, 22 were definitely peripheral, three probably peripheral, and the remainder unknown. Not a single central adenocarcinoma has been found, and $₹$ although our figures are not large it is evident that $\mathrm{O}$ the adenocarcinoma is predominantly, if not always, peripheral. Its frequency in any series therefore gives some indication of the incidence of the peripheral type. In our surgical series (Table $V_{\text {. }}$ ) the o adenocarcinoma forms $15.5 \%$, while in the post- $N$ mortem series the figure is $28.3 \%$. This is strong $\mathrm{N}$ evidence in favour of the peripheral tumour being 0 more common in the necropsy material than in the resected specimens.

It may be seen from Table VI that in every 1,000 ? cases of lung cancer there will be 201 squamous- $T$ cell carcinomata and 60 of these will be removed, giving an operability rate of $30 \%$. It is evident $\subseteq$ that the squamous-cell tumour is much more $\stackrel{\unrhd}{\mathscr{Q}}$ amenable to resection than are the other cell types, and it is likely that findings in resected squamous 8 
TABLE VI

INCIDENCE OF MAIN HISTOLOGICAL TYPES IN NECROPSY SERIES OF 159 CASES AND SURGICAL SERIES OF 207 CASES

\begin{tabular}{|c|c|c|c|}
\hline Histological Type & $\begin{array}{c}\text { Necropsy } \\
\text { Series } \\
(\%)\end{array}$ & $\begin{array}{c}\text { Surgical } \\
\text { Series } \\
(\%)\end{array}$ & $\begin{array}{c}\text { Estimated } \\
\text { Operability } \\
\text { Rate }(\%)\end{array}$ \\
\hline $\begin{array}{l}\text { Squamous-cell carcinoma } \\
\text { Adenocarcinoma } \\
\text { Oat-cell carcinoma } \\
\text { Polygonal-cell carcinoma }\end{array}$ & $\begin{array}{l}20 \cdot 1 \\
28 \cdot 3 \\
37 \cdot 1 \\
10 \cdot 7\end{array}$ & $\begin{array}{r}60 \cdot 4 \\
15 \cdot 5 \\
15 \cdot 9 \\
7 \cdot 7\end{array}$ & $\begin{array}{r}30 \cdot 0 \\
5 \cdot 5 \\
4 \cdot 3 \\
7 \cdot 2\end{array}$ \\
\hline
\end{tabular}

* The last column shows the estimated operability rate of each type assuming that the total operability is $10 \%$. It is assumed that the necropsy series is representative of lung cancer in general.

tumours are more representative of this group as a whole than are findings in the other types of tumour. In our series of 70 definitely located squamous cell tumours, $33 \%$ were peripheral and $64 \%$ central: the fact that the squamous carcinoma is more common in the surgical series $(60.4 \%)$ than in the necropsy series $(20.1 \%)$ again suggests that it is the central tumours which are selected for operation.

The site of origin of the oat-cell carcinoma is more difficult to estimate. Examination of resected specimens indicates that about $50 \%$ are peripheral (see Table IV). Table V shows that the oat-cell growths constitute approximately one-sixth of each group of small, medium, large, and giant tumours. Since the large and giant tumours are mainly peripheral while the small ones are central (see Table III) it seems likely that the oat-cell growth is as often central as peripheral. However, the resected specimens form such a small fraction of oat-cell growths (see Table VI) that these findings must be interpreted with caution.

There can be little doubt that there is a higher proportion of central tumours in a resected series than is present in lung cancer as a whole. Central tumours cause obstructive changes and chest symptoms even when small; many of them are accessible to the bronchoscope and diagnosable by biopsy. But it is the early onset of symptoms which is the most important factor in the early diagnosis, and it is for this reason that the great majority of small resected tumours are of central type. The peripheral tumours are unlikely to cause chest symptoms until they have spread to involve either the chest wall or the hilar structures; by this time many are inoperable and those that are resectable are often large.

It is our belief therefore that more than $50 \%$ of lung cancers are of peripheral type. We support the view that this factor is largely responsible for the poor prognosis and low operability rate with which lung cancer is associated.

\section{SUMMARY}

Two hundred and seven resected lung cancers have been examined. In $59.4 \%$ the site of origin was definitely located, while in a further $18.4 \%$ the probable site was found. In only $22.2 \%$ were we unwilling to commit ourselves. Tumours were classified according to the site of origin into three groups: Central, arising in one of the nominate bronchi; intermediate, arising in a macroscopically visible branch of one of the nominate bronchi; and peripheral, arising in one of the minute bronchi or bronchioles.

Of 123 definitely located tumours, $47.1 \%$ were central, $3.3 \%$ intermediate, and $49.6 \%$ peripheral. The most distinctive feature of the central tumours was bronchial obstruction; this was present in all cases, and examination of the obstructive changes in the lung beyond was found to be a useful guide in the location of tumour origin. Peripheral tumours often showed central scarring $(55 \%)$, and bronchial involvement, when present, was due to invasion either from the primary growth directly or from secondary lymph nodes.

The majority of small tumours were central, and it is concluded that the central type produces early symptoms. The giant and large tumours were mainly of peripheral type indicating that the onset of symptoms occurs at a later stage in the development of the disease.

Of those tumours whose site of origin was located, the adenocarcinoma were always peripheral and the polygonal cell growths frequently peripheral $(86.7 \%)$. Squamous-cell tumours were more often central $(57.9 \%)$ than peripheral $(36.8 \%)$, while oat-cell carcinomata were equally divided between the two groups.

Comparison between the histology of the 207 surgical cases and a post-mortem series of 159 cases gives some idea of the surgical selection, and it is concluded that the central type is favoured for resection. Since in this surgical series about one half of the tumours are peripheral, we believe that the figure for lung cancer as a whole is considerably higher than this. We support the view that this frequency of the peripheral type is a major factor responsible for the low operability rate and poor prognosis found in lung cancer.

We wish to acknowledge the help and advice of Mr. T. Holmes Sellors under whose direction one of us (J. B. W.) has been working, and we are grateful to the British Empire Cancer Campaign for a grant to study lung cancer. Our thanks are due to Professor W. D. Newcomb for his continued interest in this work, and we are greatly indebted to Dr. E. Nassau and Dr. K. R. 
Stokes for providing facilities at Harefield Hospital; also to Dr. K. F. W. Hinson for material from the London Chest Hospital. We are grateful to Dr. P. F. Baldry for his help during the early part of this work and to Mr. M. Turney for photographic assistance. Finally we wish to record our sincere appreciation to the many surgeons who have made their notes and records available.

\section{REFERENCES}

Boyd, W. (1950). The Pathology of Internal Diseases, 5th ed., p. 234. Kimpton, London.

Brown, D. E. M. (1952). Brit. J. Radiol., n.s., 25, 472

Bryson, C. C., and Spencer, H. (1951). Quart. J. Med., 20, 173.

Carlisle, J. C., McDonald, J. R., and Harrington, S. W. (1951). J. thorac. Surg., 22, 74.

Davidson, M., Smithers, D. W., and Tubbs, O. S. (1951). The Diagnosis and Treatment of Intrathoracic New Growths, pp. 79-80. Oxford University Press, London.

Franks, L. M. (1954). Ann. roy. Coll. Surg. Engl.. 15, 236.
Fried, B. M. (1938). Unio Internationalis Contra Cancrum Acta, 3 , 153.

McBurney, R. P., McDonald, J. R., and Clagett, O. T. (1951). thorac. Surg., 22, 63.

McDonald, J. R., McBurney, R. P., Carlisle, J. C., and Patton, M. M으 (1951). Ibid., 22, 62.

Ochsner, A., DeBakey, M.. Dunlap, C. E., and Richman, I. (1948) $\frac{\mathrm{d}}{\mathrm{D}}$ Ibid., 17, 573.

Patton, M. M., McDonald, J. R., and Moersch, H. J. (1951a). Ibid. 22, 83 .

- - (1951b). Ibid., 22, 88 .

Phillips, F. J., Basinger, C. E., and Adams, W. E. (1950). Ibid., 19. 680.

Prior, J. T., and Jones, D. B. (1952). Ibid., 23, 224.

Rabin, C. B., and Neuhof, H. (1934). Ibid., 4. 147.

Raeburn, C. (1951). Lancet, 2. 474.

-_ and Spencer, H. (1953). Thorax, 8. 1.

Strang, C.. and Simpson, J. A. (1953). Ibid.. 8, 11.

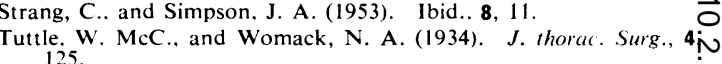
Willis. R. A. (1948). Pathology of Tumours. 1st ed.. p. 366. Butter
worth, London. 